\title{
Frontkollisjon med fjellvegg, ulykkestilfelle eller selvmord? Om selvmordsstatistikkens pålitelighet
}

Ved Finn Gjertsen

Vinterdag, middelaldrende fører au bil har i oversiktlig kurve kjørt rett frem og frontkollidert med fjellvegg. Bremsespor ble ikke observert. Bilens frontparti var trykket inn og audøde satt fastklemt $i$ bilen. Lege konstaterte at dødsårsaken var knusningsskader i hjernen, og rettstoksikologisk undersøkelse viste at avdøde var påvirket av narkotika. Det kunne ikke fastslås om dette trafikkdødsfallet var et ulykkestilfelle eller selvmord. Vurdering av om det forelå intensjon bak hendelsen gjøres på grunnlag av tilgjengelig informasjon. I noen tilfeller vil det vaere slik at det ikke kan augjøres om dødsfallet var ulykke, selumord eller forårsaket med vilje av annen person.

$\mathrm{N}$ asjonal dødsårsaksstatistikk brukes til å beskrive variasjon i selvmord over tid og mellom geografi ske områder, og bruk av selvmordsrater har utgjort en viktig del av den epidemiologiske selvmordsforskningen. M en gir offisiell selvmordsstatistikk et riktig bilde av virkeligheten?

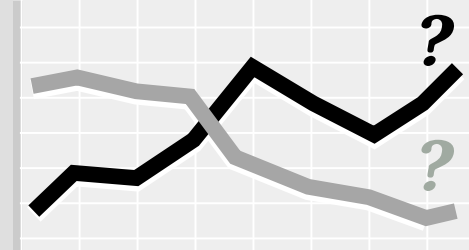

Flere har stilt spørsmål ved statistikkens pålitelighet og hvorvidt den kan brukes til sammenlikning mellom befolkningsgrupper, perioder og land (D ouglas 1967, Taylor 1982, G iertsen \& M orild 1993, Tungesvik 1999), og flere studier viser at det kan være en rekke grunner til manglende kvalitet ved pasientregistre og dødsårsaksstatistikk (Foldspang et al. 1990, Glattre\& Blix 1980, Johansson et al. 1999). I det følgende gjennomgås teoretiske tilnærminger til bruk av offisiell selvmordsstatistikk, en beskrivelse av datagrunnlag og de prinsipper og regler som ligger bak norsk dødsårsaksstatistikk, samt drøfting av statistikkens pålitelighet og sammenliknbarhet.

Det er neppe mye uenighet om at statistikk over selvmord ikke gir et eksakt bilde av virkeligheten, og at noen selvmord blir registrert under andre dødsårsaker (Gjertsen 1995). G enerelt antas det at offisielle sel vmordstall tenderer til å underestimere det "virkelige" antall tilfeller (Taylor 1982: 43-50). Estimater over størrelsen på underregisteringen varierer. Selv om dette er et sentralt spørsmål, er det også viktig å klargjøre om feilkildene er tilfel dige eller systematiske, og om feilkildene endres over tid. Det finnes statistisk metode for å håndtere tilfeldige feil, f.eks. beregning av konfidensintervall og signifikansnivå. Verre er det med systematiske feil, og denne feilkilden kan være av en slik art og omfang at datas forskningsmessige verdi reduseres til det uakseptable.

\section{Fire idealtypiske posisjoner}

Steve Taylor presenterer i boken Durkheim and the Study of Suicide (1982: 43-50) fire idealtyper hva gjelder forskeres grad av tillit til offisiell selvmordsstatistikk. Den første posisjonen kjennetegnes ved en generell akseptans til bruk av selvmordsrater. Posisjonen omfatter forskere som bruker selvmordsrater i komparative studier av utbredelse over tid, mellom land og kulturer. En slik generell akseptans av offisiell statistikk bygger på flere antak elser. For det første at det er overensstemmelse mellom forskeres definisjon av selv mord og den som brukes i statistikken (forutsetning om validiteten). Dernest at denne definisjonen anvendes på en konsistent måte (forutsetning om reliabilitet), og for det tredje at registreringsrutiner og undersøkelsesmetoder er de samme i de tidsepoker og befolkninger som undersøkes (forutsetning om sammenliknbarhet).

A nalyser i tråd med tradisjonen fra Émile Durkheim forutsetter at selvmordsrater er valide, reliable og tverrkulturelt sammenliknbare. Det kan imidlertid stilles spørsmål ved statistikkens reliabilitet, eller nøyaktighet, og noen vil følgelig være tvilende til om offisiell selvmordsstatistikk er en brukbar indikator på den "virkelige" utbredelsen. To sett av argumenter dominerer denne tvilen. Det første kaller Steve Taylor posisjon for begrenset akseptans. A rgumentasjonen her er at selvmordsrater er nyttige som et grovt mål på selvmordshandling, men de er ikke reliable for tverrkulturell komparativ analyse. Taylor (1982) mener denne posisjonen dominerer blant forskerne innen fagområdet, og viser til bl.a. Farberow og Stengel. Innenfor denne posisjonen argumenteres det for at bedre registreringsprosedyrer kan øke datakvaliteten. Posisjon for skepsis til selvmordsrater er derimot tvilende til verdien av analyser basert på selvmordsrater grunnet statistikkens lave reliabilitet. $M$ an er også tvilende til om validitet er holdbar, selv innenfor samme land/kultur i en kort tidsperiode. Denne posisjonen har i det vesentlige vært representert ved psykiatere og leger. Ut fra klinisk erfaring har disse pekt på at diskrepansen mellom de krav til bevisførsel som stilles av Coronor (embetsmann som forestår likskue) for å fastslå at et dødsfall var selvmord og de vurderinger av dødsårsak som gjøres av kliniker, er så stor at det gjør selvmordsrater uegnet til forskningsformål. Ruth Ettlinger har f.eks. argumentert for at de registrerte selvmordene er sterkt selekterte, og at forskjeller som fremkommer i komparative analyser i det vesentlige reflekterer forskjell i registrering (Taylor 1982:47).

Den fjerde posisjonen Taylor beskriver, omtales som avvisning av offisielle rater som uttrykk for fenomenet selvmord. Denne posisjonen kan knyttes til fenomenologi og etnometodologi, og her argumenteres det mer prinsipielt om hvor vanskelig/umulig det er å konstruere offisielle rater om en avviken de handling som selvmord.

Taylor har beskrevet posisjoner som kan bidra til å klargjøre variasjon i bruk av selvmordsrater $\mathrm{i}$ analytisk virksomhet. I det følgende gis en beskrivelse av de prosesser som ligger bak selvmordsstatistikken i N orge. 


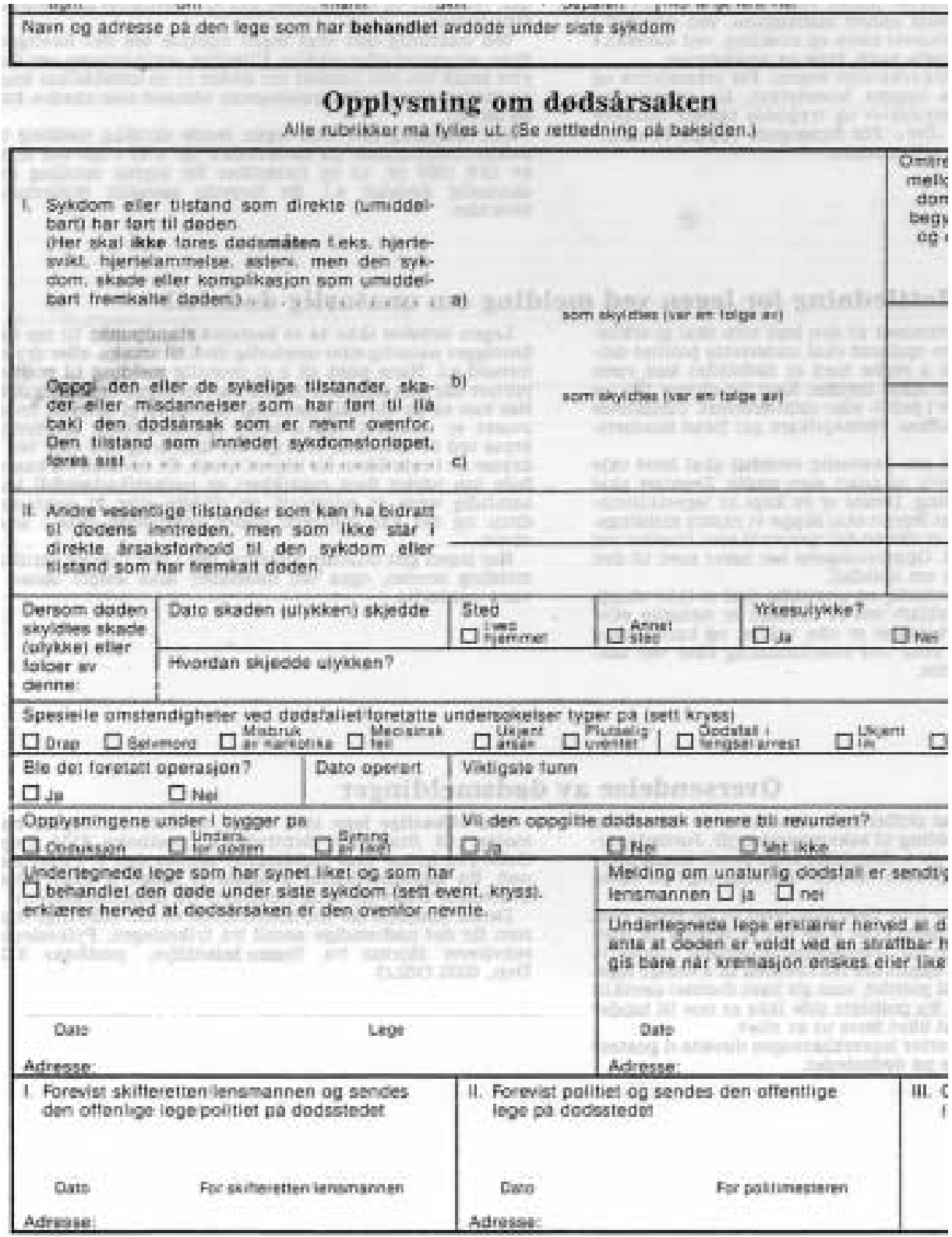

IK-1025 B

\section{Registrering av dødsårsak}

Statistisk sentralbyrå har hatt ansvaret for utarbeidelse av offisielle dødsårsaksstatistikk siden 1925. Fra 1939 overtok Statistisk sentralbyrå også ansvaret for klassifisering av dødsårsak til bruk i dødsårsaksstatistikken, noe som tidligere var foretatt av offentlige leger. Denne endringen innebar en kvalitetsforbedring i og med at material et nå ble behandlet på en langt mer ensartet måte ( $G$ jertsen 2000).

Som medlem av Verdens helseorganisasjon har $\mathrm{N}$ orge forpliktet seg til å utarbeide dødsårsaksstatistikk i samsvar med den internasjonale sykdomsklassifikasjon (ICD) med virkning fra 1951. I praksis innebærer denne forpliktelsen at opplysning om dødsårsak gis på en standardisert måte, jfr. feltene I og II på legeerk læringen om dødsfall. Videre, at statistikken utarbeides etter ICDs prinsipper og retningslinjer for klassifisering og koding av dødsårsak.
Klassifisering og koding av ytre omstendigheter til dødsfall er nødvendigvis beheftet med usikkerhet. D enne usikkerheten kan dels skyldes mangelfull tilgang til opplysninger om ytre omstendigheter, dels at bestemmel se av ytre omsten dighet baseres på skjønn (G jertsen 1992). Det første er tilfellet når dødsmeldingen gir mangelfull eller ufullstendig informasjon. Den skjønnsmessige vurdering som ligger til grunn, vil variere. I noen tilfeller er det ikke særlig tvil om hva som skjedde. I andre tilfeller vil skjønnet fort nærme seg gjetning når det skal avgjøres om dødsfallet var et ulykkestilfelle, selvmord eller drap. I tilfeller hvor det er stor tvil om dødsfallet var et ulykkestilfelle eller selvmord, vil mer informasjon ikke nødvendigvis innebære at klassifiseringen blir lettere, fordi usikkerheten viser tilbake til individets uklare motiv og ønske.

\section{Usikker hensikt}

I den 10. revisjon av den internasjonale sykdomsklassifikasj on er ytre årsaker til skader og dødsfall inndelt i følgende hovedgrupper (ICD-10 1992):

\section{- U lykker, V 01-X59.}

- Selvmord og villet egenskade, X60-X84.

- Vold og overfall, X 85-Y09. å angi tilstander som kan relateres til den hendelsesrekken som direkte ledet til døden. Del II er beregnet på andre vesentlige tilstander som bidro til døden, men som ikke stod i direkte årsaksforhold til den sykdom eller tilstand som har fremkalt døden. Verdens hel seorgani sasjon innførte prinsippet om koding av underliggende dødsårsak i 6. revisjon av ICD. Formålet med dette prinsippet var å øke dødsårsaksstatistikken s sammen liknbarhet. Den dødsårsak som velges som underliggende dødsårsak, brukes i internasjonal årsaksspesifikk mortalitetsstatistikk. M ed underl iggen de dødsårsak menes:

a) den sykdom eller skade som startet rekken av de sykelige tilstander som ledet til døden, eller

b) de ytre omstendigheter ved den ulykke eller voldshandling som var årsak til den dødelige skade.
- U klart om skade er påført med hensikt, Y 10-Y 34.

- Lovhjemlet inngripen og

- Komplikasjon ved medisinsk og kirurgisk behandling, Y 40-Y 84.

- Senvirkninger etter ytre årsak til sykdom eller død, Y 85-Y 89.

Kategorien "U klart om skade er påført med hensikt" brukes i tilfeller hvor det ved medisinsk eller rettslig undersøkelse ikke har vært mulig å skille mellom ulykker, selvmord eller drap. Etter at denne kategorien ble innført i 8. revisjon av lom de nordiske land hva gjelder bruk av årsaksgruppen "U sikker ytre årsak". $\mathrm{N}$ orge har kodet få tilfeller i denne katekrigshandling, Y 35-Y 36. ICD, har det vært forskjellig praksismel- 
gorien i motsetning til Sverige. Ved sammenlikning av ulykkes- og selvmordsstatistikk bør det følgelig utvises en viss forsiktighet ( $\mathrm{H}$ ealth Statisticsin the N ordic Countries 1997:123-136). Resultater fra en undersøkel se om sammenliknbarhet av europeisk dødsårsaksstatistikk viser til dels betydelige forskjeller i bruk av nevnte kategori (C omparability and Q uality Improvement in European Causes of Death Statistics 1999). Ratio mellom rater for årsaksgruppene usikker ytre årsak og selvmord for menn i 1994 varierte mellom 1,16 (Portugal) og 0,02 (H ellas). Dette betyr altså at i Portugal var raten for dødsfall av ukjent ytre årsak blant menn høyere enn selvmordsraten. A ndre land med høy ratio blant menn i 1994 var England $(0,43)$, Sverige $(0,31)$, Danmark $(0,23)$ og Frankrike $(0,21)$. Til sammenlikning var ratio i N orge kun 0,05.

La oss se på tre eksempler på hvordan opplysning om dødsfall av skader kan være gitt på "L egeerklæring om dødsfall/melding om unaturlig død":

\section{Eksempel 1}

I a H ode-, bryst- og bukskader

O pplysning annet sted på dødsmeldingen: Frontkollisjon med trailer

\section{E ksempel 2}

I a Drukning?

\section{Eksempel 3}

\section{I a Forgiftning med medikament?}

Kommentar: A nta at det i tillegg ble foretatt rettslig obduksjon i disse tre tilfellene, samt at det i rapportene fremgår at ytre årsak til skade/forgiftning ikke lot seg fastslå. Koden som brukes som underliggende dødsårsak, vil i nevnte tilfelle ligge i kategorien usikkert om skaden var uhell eller påført med hensikt.

\section{Grunnlag}

D ødsårsaksstatistikken utarbeides på grunnlag av opplysninger på «Legeerklæring om dødsfall/melding om unaturlig dødsfal|» eller «Dødsmelding fra lensmann til den offentlige lege». Videre innhentes tilleggsopplysninger fra K reftregisteret (kreftdødsfall), M edisinsk fødsel sregister (dødfødte og dødsfall i første leveår), Statistisk sentral byrås statistikk over veitrafikkulykker, obduksjonsresultat fra sykehus og rettsmedisinske laboratorier.
I samarbeid med medisinsk konsulent innhentes også tilleggsopplysninger fra lege/sykehus når opplysning om dødsårsak og ytre skadeårsak på dødsmel dingen er mangelfull eller uklar. Innhenting av tilleggsopplysninger og tilbakespørring til lege/sykehus er av vesentlig betydning for å sikre kvaliteten på statistikken. I tillegg innhentes det sivile opplysninger (f.eks. bosted) fra Det sentrale folkeregisteret i Skattedirektoratet som bygger på opplysninger i lokale folkeregistre.

\section{Nedgang i selvmord - dårligere registrering?}

Fra slutten av 1960-årene til slutten av 1980-årene økte selvmordshyppigheten i N orge, særlig sterk var økningen blant unge menn. Deretter viser offisiell selvmordsstatistikk en betydelig nedgang ( 30 prosent) i løpet av perioden 1988-1996 (Dødsårsaker 1996). Rettmedisinerne G iertsen og M orild (1993) har argumentert for at mye av den registrerte økningen kan forklares med bedre registreringsrutiner, mens Tungesvik (1999) stiller seg sterkt tvilende til at nedgangen i selvmordsrater i 1990-årene gjenspeiler realitetene med referanse til egen og andres kliniske erfaring. $G$ år vi noen tiår tilbake i tid, var det en utbredt oppfatning at forklaringen på at N orge hadde så lav selvmordsdødelighet sammenliknet med Danmark og Sverige, i stor grad skyldtes dårligere registrering.

Kan økningen i selvmord i 1980-årene forklares med bedre registreringsrutiner, og har disse rutinene blitt svekket i 1990årene med den konsekvens at selvmordstallet reduseres? Statistisk sentralbyrå har over lengre tid hatt rutiner for innhenting av tilleggsopplysninger når opplysning om ytre årsak til den dødelige skaden er ufullstendig eller mangelfull. Slik tilbakespørring til utsteder av dødsmelding er anbefalt av Verdens helseorganisasjon og gjennomføres i varieren de omfang i medlemsland. En undersøkelse som vurderte betydningen av denne tilbakespørringen i N orge, viser at den førte til at antall selvmord økte med 20 prosent

(Glattre \& Blix 1980). Slike rutiner kan likevel ikke forhindre at det hefter usikkerhet ved tallet på selvmord. Det avgjørende er imidlertid om denne usi kkerheten har endret seg i løpet av de seneste tiår.
På bakgrunn av den observerte økningen i selvmord i N orden og andre europeiske land siden slutten av 1960-årene, besluttet N ordisk samarbeidsnemnd for medisinsk forskning (N O S-M) i 1977 å nedsette en nordisk forskningsgruppe vedrørende selvmord (Juel-N ielsen \& Retterstø| 1982). Et delprosjekt bestod i en gjennomgang og analyse av registreringspraksis, prinsipper og rutiner i meldeog registreringssystemene i de enkelte nordiske land. Dette ble gjort med spesielt henblikk på om den påfallende lave selvmordsdødeligheten i N orge, sammenliknet med nivået i Finland, Sverige og Danmark, skyldtes forskjeller i registreringspraksis, eller om det er uttrykk for reelle forskjeller. Konklusjonen fra denne del av studien var at selvmordsregistreringen hadde samme grad av pålitelighet $\mathrm{i}$ alle de fire land, og at norsk selvmordsstatistikk ble funnet å være minst like nøyaktig og pålitelig som i Finland, Sverige og Danmark. (Juel-N ielsen et al. 1987)

To undersøkelser anslår at nivået på underregistering av selvmord i N orge er under 10 prosent. R ettsmedisinerne G iertsen og M orild (1993) anslår at "mørketall" på slutten av 1980-årene var så lavt som mellom 5-10 prosent, men at det i 1960-årene var betydelig høyere, anslagsvis rundt 25 prosent. I en studie om selvmordsstatistikkens pålitelighet basert på et empirisk materiale fra 1978-81 ble det konkludert med at det er liten grunn til å anta offisiell underregistrering av selvmord (Ekeberg et al. 1985). H vis tvilstilfellene tas med, anslår forfatterne at underregistreringen er lavere enn 10 prosent.

Den endring i selvmordsrater som er observert i N orge de siste tiårene, kan i liten grad tilbakeføres til endringer i datagrunnlag, regler og retningslinjer for koding av dødsårsaker. $H$ vorvidt andre feilkilder som endringer i holdninger til selvmord hos leger, rettsmedisinere og politi som foretar vurdering av ytre årsak til dødsfall, vet man lite om. Det synes følgelig rimelig å konkludere med at endring i selvmordsrater i $\mathrm{N}$ orge de seneste tiår gjenspeiler reelle endringer, men har samtidig vist at internasjonale sammenlikninger må gjøres med forsiktighet. 


\section{Litteratur}

Comparability and Q uality Improvement in E uropean $C$ auses of $D$ eath Statistics. Steering group no 2. M inutes of the meeting. EC DG V/F3 SO C 98 20108. Luxembourg: 10 December 1999.

Douglas J D. The social meaning of suicide. $\mathrm{N}$ ew Jersey: Princeton U niversity Press, 1967.

D ødsårsaker 1996. N OC C 591. 0 slo-

K ongsvinger: Statistisk sentral byrå, 2000.

Ekeberg $\varnothing$, Frederichsen $P$, , H olan L . Selvmordsstatistikkens pålitelighet $\mathrm{i} \mathbf{N}$ orge. Tidsskrift for Den norske lægeforening 1985; 105 (2):123-7

Foldspang A , Juul S, OIsen J Sabroe S.

Epidemiologi. Sygdom og befolkning. 2. udgave. København: M unksgaard, 1990: 259-298.

Giertsen JC, M orild I. Påliteligheten av den norske selvmordsstatistikken. N ordisk M edicin 1993; 108 (2): 58-9.

G jertsen F. D ødelighet ved ulykker 1956-1988. Rapporter 92/8. O slo: Statistisk sentral byrå, 1992.

G jertsen F. Selvmord og ulykker. I: Sosialt utsyn 1993. Statistiske analyser. O slo-K ongsvinger: Statistisk sentral byrå, 1993: 97-105.

G jertsen F. D ødsårsaksregisteret og forskning. Tidsskrift for Den norske lægeforening 2000; 120 (6): 723-5.

G lattre E, Blix E. En vurdering av dødsårsaksstatistikken. Feil på dødsmeldingene. Rapporter 80/13. O slo: Statisti sk sentral byrå, 1980.

H ealth Statistics in the N ordic Countries 1997. København: N O M ESK O 56:1999

IC D-10 International Statistical C lassification of $D$ iseases and $\mathrm{H}$ ealth $\mathrm{R}$ elated Problems. Tenth R evision. Volume 1. G eneva: W orld H ealth O rganization, 1992.

Johansson $L A$, Bille $H$, A honen $H, H$ elgadòttir $S$, Gjertsen $F$, Lönn $Y, N$ ielsen J: C auses of D eath Statistics. I: $\mathrm{H}$ ealth Statistics in the N ordic C ountries 1997. København: N O M ESKO 56:1999. Juel-N ielsen N, R etterstøl N : Selvmord i N orden. N ordisk M edicin 1982; 97 (11): 265-6.

Juel-N ielsen N, Retterstøl N, Bille-Brahe U : Suicide in Scandinavia. $A$ report on the internordic research project. A cta Psychiatrica Scandinavica 1987; suppl. 336: 1-81.

Taylor S. D urkheim and the Study of Suicide. London: The M acM illian Press, 1982.

Tungesvik H O . Sjølmordsstatistikken. A ftenpostens morgenutgave 8. september 1999: 17.

Finn G jertsen er cand.sociol. (1987) og rådgiver i Statistisk sentralbyrå, Seksjon for helsestatistikk, og har i flere år hatt faglig ansvar for Dødsårsaksregisteret og den nasjonal e dødsårsaksstatistikken. For tiden arbeider han bl.a. med et prosjekt om hel seinformasjon ssystem i Botsdenser i selvmord, datagrunnlag, kvalitet og sammenliknbarhet. 